\title{
Beyond Brinkmanship: The Implication of South China Sea Conflicts on China's Soft Power in Southeast Asia
}

\author{
Randy W. Nandyatama
}

\author{
Universitas Gadjah Mada, Indonesia
}

\begin{abstract}
While contemporary scholarly literatures on South China Sea conflicts have been dominated by hard power calculations, some other aspects remain under-researched. Rather underplayed in the existing literature is the question on the political implication of the conflicts on China's soft power in the region. In responding to this issue, this article tries to carefully investigate the nature of the China's soft power and the linkage between the increasing Chinese assertive measures in the South China Sea and the foundation of China's soft power in the region. Through some cases of China's skirmishes with Southeast Asian countries on the South China Sea between 2009 and 2012, this article argues that Beijing's increasing hard power measures have induced growing threat perceptions in the region. This very context not only signals a distinct dissonance of Beijing's image in Southeast Asia but also creates surging discontents and rejections to China's role and political position in the region. Ultimately, China's perceived inappropriate hard power measures affect its soft power, particularly in eroding the reputation of being a benign political entity as its source of soft power in Southeast Asia.
\end{abstract}

Key words: China-Southeast Asia, soft power, threat perception

\section{Introduction}

The twenty first century has generally deemed to be an important era for China. Along with its remarkable transformation and modernization since 1978, China's political power in the international arena began to expand rapidly. The poor and weak China has become a center of attention in global politics (Brahm, 2001; Senkar, 2004). The modernization of its military posture and the fast growing of its economy have changed how other countries engage with Beijing. Its neighboring countries have started to build friendly interactions with the rising China, including Southeast Asian countries. Nevertheless, concomitant with its growing international profile, Beijing also started to have strong military measures, particularly in the South China Sea (Wong, 2010; Thayer, 2010, pp. 2-6; Jayakumar, 2011). Along with existing conflicts over territorial claims between China and some Southeast Asian countries, the growing China's assertive measures eventually created a greater political concern in the region. 
Indeed, there is a general tendency in privileging the preponderance of hard power calculations in the International Relations literatures (Baldwin, 1999, pp. 173-183). This specifically exists in the scholarly literature on South China Sea conflicts (Green \& Daniel, 2011; Karim \& Tangguh, 2016) However, as the rise of China increasingly influences contemporary global politics, it becomes important to not only investigate China's actual capability in terms of its traditional 'hard' power in influencing Southeast Asia, but also assess its soft power and the implication of its 'hard power' measures on its soft power in the region. This is not without a clear logic. In an event which involves hard power measures, for instance, it is easy to prioritize hard power's examination and overlook its soft power aspect, such as how the United States (US) calculate its hard power capability in 'securing' Iraq and Afghanistan. However, it is important to note that US hard power measures as part of global 'war on terror' campaign, in fact, weaken its 'soft power' in the Middle East (Nye, 2004, pp. 42-44). Reminiscing this context, a similar concern for China may arise, especially in light of the rising tension in the South China Sea conflicts. As such, it is important inquire what is the nature of China's soft power in Southeast Asia? And how South China Sea conflicts affect its soft power in the region?

Echoing Todd Hall's (2010) effort in investigating soft power as a category of analysis, this article underlines the logic of how soft power, especially in the form of reputation, serves as an important reference for political interactions in the international arena. Within this context, the capability to project and sustain particular reputations 'provide states with issue-specific forms of influence' (Hall, 2010, pp. 209). This logic is well apparent in China's foreign policy, especially as a logical pathway for Beijing's soft power in Southeast Asia. Nevertheless, since this article emphasizes good reputation as the source of soft power, its existence and foundation can be easily weakened by negative perceptions, such as excessive or inappropriate use of hard power. Hence, we can see that Beijing's growing assertiveness, particularly the utilization of hard power measures in managing the South China Sea conflicts, has induced the burgeoning of 'threat perceptions' among Southeast Asian countries and eroded China's reputation as its source of soft power.

Specifically, in investigating the dynamic quality of Beijing's soft power in Southeast Asia and the linkage between the growing 'threat perception' from China's hard power measures and its soft power in in Southeast Asia, this article gathers qualitative data from the series of surveys on China's popularity as well as elites' opinions and statements on China (including Beijing's increasing hard power measures in South China Sea). Indeed, given the complex relationship between China and Southeast Asia, including the different characteristics of mainland Southeast Asia and maritime Southeast Asia in dealing with China, it is impossible to claim that there is a solid and definitive Southeast Asian perception 
of China (Percival, 2007; Storey, 2013). However, this does not mean that we cannot see a growing trend of how some Southeast Asian countries respond to Beijing's growing assertive measures in the South China Sea. As a result, this article reviews the existence and quality of China's soft power in two countries that represent different geo-political groupings in Southeast Asia, namely Vietnam and the Philippines. Despite this decision may also have a certain bias, this decision is based on the data availability. Existing survey data on popularity of China in Southeast Asia only covers particular countries like Vietnam and The Philippines. The gathered data also only covers the time span of 2000 to 2012. This is aimed to provide a better analysis on the impact of South China Sea conflict on China's soft power. In 2013, Beijing formulated a new policy-i.e. One Belt and Road-which alters the political map of China-Southeast Asia relations.

Ultimately, this article evaluates China's approach in exercising its soft power projection in Southeast Asia and underlines how inappropriate hard power measures eventually entangle with soft power. Specifically, article is structured into four main parts in which each element is taken into account. Following this introduction, the next part covers on the conceptualization of soft power as the foundation of this research. The second part will focus the nature of China's soft power in the Southeast Asia. The third part of this article broadly elaborate the case of the South China Sea conflicts, especially in assessing Southeast Asian responses. In the end, it will discuss the linkages of the South China Sea conflicts to the contemporary China's soft power.

\section{Conceptualizing Soft Power}

The term 'soft power' is a unique notion. It becomes a distinct phrase as it refers to a large spectrum of non-military hard power in the international arena. It is also generally adopted in implying the various non-tangible modalities which support a particular state to persuade or influence the preferences of other states (Hall, 2010, pp. 190). This concept is rooted from E. H. Carr's (1949) notion of 'power over opinion' which acknowledges that public and elite opinion is one of the essential elements in the international arena and it forms a distinct political force from military or economic power. Steven Lukes (2005, pp. 25-29) advances further this idea into the so-called 'the third dimension of power'-i.e. the ability to affect and shape the formation of perceptions and preferences in ensuring the acceptance of a particular role in the existing order, and vice versa.

However, only after Joseph Nye writes about 'power' along with the growing interdependent and transnational issues and actors in international politics, 'soft power' becomes a well-known concept in IR literatures. Nye (2005, p. x) specifically defines soft power as 'a country's ability to get what it wants through appeal and attraction.' This concept underlines the logic of how various viable resources can be applied to make other countries acquire more positive beliefs and perceptions which eventually resulted 
in the targeted states' greater tendency to respect and give amicable response. Thus, Nye's exposition of soft power becomes a ground-breaking analytical tool, especially for identification of the new trend in culture and positive image projection from a rising state in the world, such as China.

At this juncture, it is important to note that Nye offers a relational approach as a new model in making sense the existence of soft power in international politics. Nye notes that soft power is not always fungible. In other words, the effectiveness of soft power depends on how each country utilizes its 'ability to influence other's behavior'. As such, a particular country does not have an inherent soft power; yet, it has to be generated from the process of attribution among the international actors. Any country will get the result it prefers because the other states realize the legitimacy of the respective state and follow its narrative (Huang \& Sheng, 2006, pp. 23-34). Therefore, the study of soft power in this article is not focused on the quantity of soft power, but in the context of how the source of soft power turns into an active element in shaping other countries' behavior.

Nevertheless, sinologists have realized some difficulties in assessing China's soft power (Yan, 2006, pp. 6). Despite major works on China's soft power, such as Kurlantzick (2007) and Lampton (2008), researches often focus on identifying and predicting the impact of Beijing's soft power and pay less attention to how does it actually operate. In this regard, looking at Hall's (2010) logic of the various sources of soft power may offer an important analytical tool. For him, a set of issue-specific reputations will support a particular country on the respective issue, signifying the so-called 'reputational power' (Hall, 2010, pp. 209). Along with the conditions which are predominated by the inadequacy of Beijing's contemporary leadership in the global arena and the characteristics of suspicion and mistrust between countries in Asia, the primary source of China's soft power basically lies on its reputation. In the manner where every actor interprets each other, the image (mianzi) of Beijing reputation in the international arena is important for the decision-making process of other actors (Hall, 2010, pp. 207-211).

Certainly, the examination of soft power needs to also acknowledge the intertwining mechanism between soft power and hard power. As Nye (2004, pp. 25-30; Li, 2009, pp. 4-5) notes before, soft power needs to be welded in a tactical manner in the realm of intersubjectivity among international actors. As such, the research on soft power demands a further exposition in its structure of action and the surrounding influencing factors, including whether hard power measures exist. At this point, one cannot simplify the structure of hard power as the utilization of military force in destroying and paralyzing the enemy, but on a much broader aspect, especially in terms of its ability in imposing clear directive through its consequences for other countries and 
generating a distinct perception among other entities.

In the case of the complex relations between China and Southeast Asia, the analysis of soft power, thus, relies on other countries' perception of Chinese reputation. It implies that hard power measures and the basis of soft power are interlinked, as both powers may share the same juncture, namely 'threat perception'. By adopting the notion of threat perception, this research tries to elucidate the crucial conceptual bridge in understanding how China's hard power measure affects its soft power and political images, particularly along with the repercussion of actual misconduct or 'be perceived as misconduct' measures (Li, 2009, pp. 5). Moreover, it also indicates the subjective nature of international actors, especially the elite, as they perceive the growing external hard power measures (Tilman, 1984, pp. 2-3; Novotny, 2010, pp. 67-68).

\section{The Nature of China's Soft Power in}

\section{Southeast Asia}

Along with the onset of the postCold War era, Beijing's foreign policy was gradually transformed with renewed vigor. There was a strong willingness to sustain its rapid economic development through being an active actor in the international arena. However, at the same time, China's meteoric economic rise started becoming a global spotlight. Often being compared with and likened to the rise of Germany and Japan during the preWorld War II, Western scholars regarded the rise of China as a new global concern, forming the so-called 'China threat' theory (Mearsheimer, 2001， pp. 396-402; Krauthammer, 1995, pp. 72; Roy, 1996, pp. 758-771). By mid 1990s, this narrative started to influence some major powers' political behaviors against China. As a result, a growing 'containment' policy towards Beijing seemingly manifested in the international arena, such as the USJapan alliance in 1996 as a gesture in restraining Chinese ambitions (Nye, 2002, pp. 22), and US effort in persuading the European Union to retain its armsembargo on China (Archick, Grimmett, \& Kan, 2005).

Against the abovementioned backdrop, Beijing became fully aware that the growing anxiety over 'China threat' theory could negatively impact its prospect for development. Besides that, considering that the modern China was initially emerged as mere one of developing countries in the world, Beijing had a limited claim and legitimacy, especially in terms of its source of soft power (Wang, 2011, pp. 37-53). In this regard, China realized the need for overcoming the suspicion and mistrust from its regional environment and encountering the growing China threat theory with a careful projection of its soft power via promoting a better 'reputation' in the international arena (Deng, 2006, pp. 186-206). In seemingly echoing Hall's categorization of reputational power, Beijing underlines how building a certain new image and reputation as a 'benign' rising country will help inducing other states to respect and support China's 
agenda and position at the international arena.

As a response, Chinese government and scholars have rapidly began to endorse a new consideration in improving national image, especially through the domestic debate on how China should encounter 'China threat' theory and pursue its national goal. Zheng Bijiang, for instance, notably points out the conception of 'the development path of China's peaceful rise' (zhongguo de heping jueqi fazhan daolu). Zheng (2005, pp. 18) stresses that China requires tactical measures to sustain a peaceful international environment, including the cultural support for the country and coordination of interests in its various sectors to create a better 'climate' for its development. Beijing soon adopted this concept through Prime Minister Wen Jiabao's speech during a visit to the US in 2003, where for the first time China officially stated the determination of its rising power as a 'peaceful' country. Subsequently, after some minor alteration, Beijing finally used the term of 'peaceful development' as its official policy (The State Council Information Office, 2006).

Indeed, in supporting the sustainability of its rapid growth, tapping into soft power has become one of China's foreign policy agenda. The concern in creating a better international environment for China eventually manifested through the projection of soft power, especially in the form of campaigning China's commitment for creating 'peaceful development' and 'harmonious society' (Guo \& Jean-Marc, 2008). In all, there is a strong element of the efforts in building 'benign' reputation and transforming other countries' perception to benefit China's interests as its core policy framework. This is also reaffirmed by Hu Jintao's (2007) statement which emphasizes the necessity to develop Chinese cultural soft power in dealing with domestic needs and the increasing global challenges.

In the context of China-Southeast Asia relations, Beijing's commitment for building its soft power in the region is essential. Many countries in the region, particularly maritime Southeast Asian countries, have often been having a suspicion against China and maintaining close relations with the US and its allies (Cho and Park 2013; Kristof, 1998). Therefore, Southeast Asian reaction to China can be deemed to be as a litmus test for its soft power projection (Rozman, 2010, pp. 201). Within this context, Beijing finally developed a set of slogans, such as 'friendly and good-neighbourly' ( $m u$ lin you hao) and 'benevolence towards and partnerships with neighbors' (yi lin wei shan, yu lin wei ban), in elucidating China's new approach to the region (Tang, Mingjiang, \& Acharya, 2009, pp. 17). In responding to Asian Financial Crisis, for instance, Beijing took the risk not to devalue its reminbi and agreed to give additional financial support for some countries in Southeast Asia (Jones \& Michael, 2007, pp. 169-172). In contrast to the US which supported the IMF's unpopular austerity packages, Beijing's foreign policy signaled a real 
transformation in its engagement with Southeast Asia (Percival, 2007, pp. 8). Moreover, Beijing also manifested its soft power campaign with being the first nonmember of the Association of Southeast Asian Nations (ASEAN) to sign the Treaty of Amity and Cooperation (TAC) with ASEAN in 2003 and the support for the East Asia Summit (EAS) in 2005 (Pan, 2008, pp. 39-62; Storey, 2011a, pp. 64-87). This signals the logic of China's soft power projection-i.e. its determination in promoting a 'benign' image and assuring the neighboring countries with amicable foreign policy implementation.

Reacting to China's soft power projection, Southeast Asia demonstrated a positive gesture towards China. Beijing's soft power projection have proven significantly in boosting Southeast Asia's good perception of China. The initial East Asia Summit (EAS) formation, for instance, is aligned with Beijing's preference to limit regionalism in East Asia (Nanto, 2008; Sutter, 2008, pp. 261282). In fact, this condition is also verified by how Southeast Asian eyes view China has transformed from 'the state most often feared into, for most but not all, a perceived partner' (Percival, 2007, pp. 3). Besides that, a public opinion survey in six Southeast Asian countries by the Japanese Foreign Ministry has indicated the rapid increase of China's influence in the region, even compared to that of Japan (Er, Narayanan, \& Colin, 2010, pp. 44-66).

At this juncture, China has demonstrated its ability to put project a distinct reputation as a benign rising power in Southeast Asia. Denoting with the Nye's conceptualization of soft power which emphasizes the ability to influence other countries' perception and behavior, this condition affirmed the existence of China's source of soft power in shaping Southeast Asia's preference in accordance with its intention. Nevertheless, Beijing's soft power projection in this region is not progressing on a linear pattern. In fact, China's soft power is, somehow, complex and non-static, especially after the growing tension in the South China Sea conflicts since 2009.

\section{Beijing's Increasing Hard Power Measures in the South China Sea}

Although there was an improvement in Southeast Asian's perceptions and attitudes towards China after the end of Cold War era, some existing problems in China-Southeast Asia relations still exist. There are at least two important issues in here. First, looking back to the long history political interactions in the region, including the memory of China's hegemony over its periphery, there is a widely shared attitude among elites which stresses the notion of sovereignty and power politics to as the means to survive (Kang, 2003; Katzenstein \& Rudra, 2004). Second, there are some uncertainties about the rise of China, especially the enigmatic decisionmaking process in Beijing and the question of what role China will want to play in the international arena. Both of these issues eventually lead to the formation of the general pattern of many Southeast Asia countries' suspicion 
towards China rise (Kristof, 1998, pp. 3749; Cho \& Park, 2013).

Being perceived as both opportunity and latent threat, many countries in Southeast Asia generally pursue a tactical approach in gradually engaging with China and maintaining the balancing options in case of engagement measure fails (Acharya, 2003a, pp. 2). This generates the variety of each state' reactions towards China, ranging from the bandwagoning trend to the inclination of acting to balance against China (Kang, 2003, pp. 58; Acharya, 2003b, pp. 150-153). Accordingly, the issues of power politics, geopolitics, the economic gap and dependence as well as the potential of the apparent territorial conflicts in the South China Sea added up to the strategic calculations of each country. Thailand, for instance, seem to have a better perception of China than Vietnam or the Philippines, which perceive themselves as the 'frontline' of China's possible aggression.

The conflict is rooted in the multiple overlapping territorial claims. Southeast Asian countries such as Malaysia, Vietnam, the Philippines, Brunei, had laid official claim to several territorial features in the South China Sea in the mid-1960s and 1970s (Emmers, 2010, pp. 66-77; Ott, 2011, pp. 1). However, many of these claims overlapped with China's claim, which declared the area limited by nine dashed lines covering the South China Sea as its territory in 1947. Indeed, it is important to note that China has been only demonstrated a limited physical claim in the initial era, comparing to the other claimants which have a closer distance to the disputed area. Beijing has only started its active claim along its growing military power, such as the 1974 China-Vietnam battle of the Paracel Islands and 1988 China-Vietnam skirmish over Spartly Islands (Shirk, 2007, pp. 114). China believes that the other claimants have been taking advantage for a long time, especially in exerting its claim over and extracting resources from the South China Sea. This logic pushes Beijing to pursue a more active measures ( $\mathrm{Li}, 2008)$.

Despite some efforts in managing the conflicts, such as the agreement of the Declaration on the Conduct of Parties in the South China Sea (DoC) in 2002, there have been growing hard power measures on the South China Sea (Banlaoi, 2010). Indeed, since 1999 China had been annually declared unilateral fishing ban in the South China Sea from June to July. However, since 2009, Beijing extended the fishing ban from May to August (Macikenaite, 2014). Moreover, in reacting to Malaysia-Vietnam joint submission of the clarification of their claim on the 'southern part of the South China Sea' to the Commission on the Limits of the Continental Shelf (CLCS) under the United Nations Convention on the Law of the Sea (UNCLOS) on May 2009, China declared its rebuttal to the claim (Rajagobal, 2016). Subsequently, Beijing made unprecedented move in enforcing its jurisdictional claims in the South China Sea, especially by actively dispatching its patrol vessels to the South China Sea to protect Chinese fishing vessels outside the period of its unilateral fishing ban (Thuy, 
2011). This certainly marked a significant China Sea conflicts. change in Beijing's approach to the South

\section{Map 1. Conflicting claims over South China Sea}

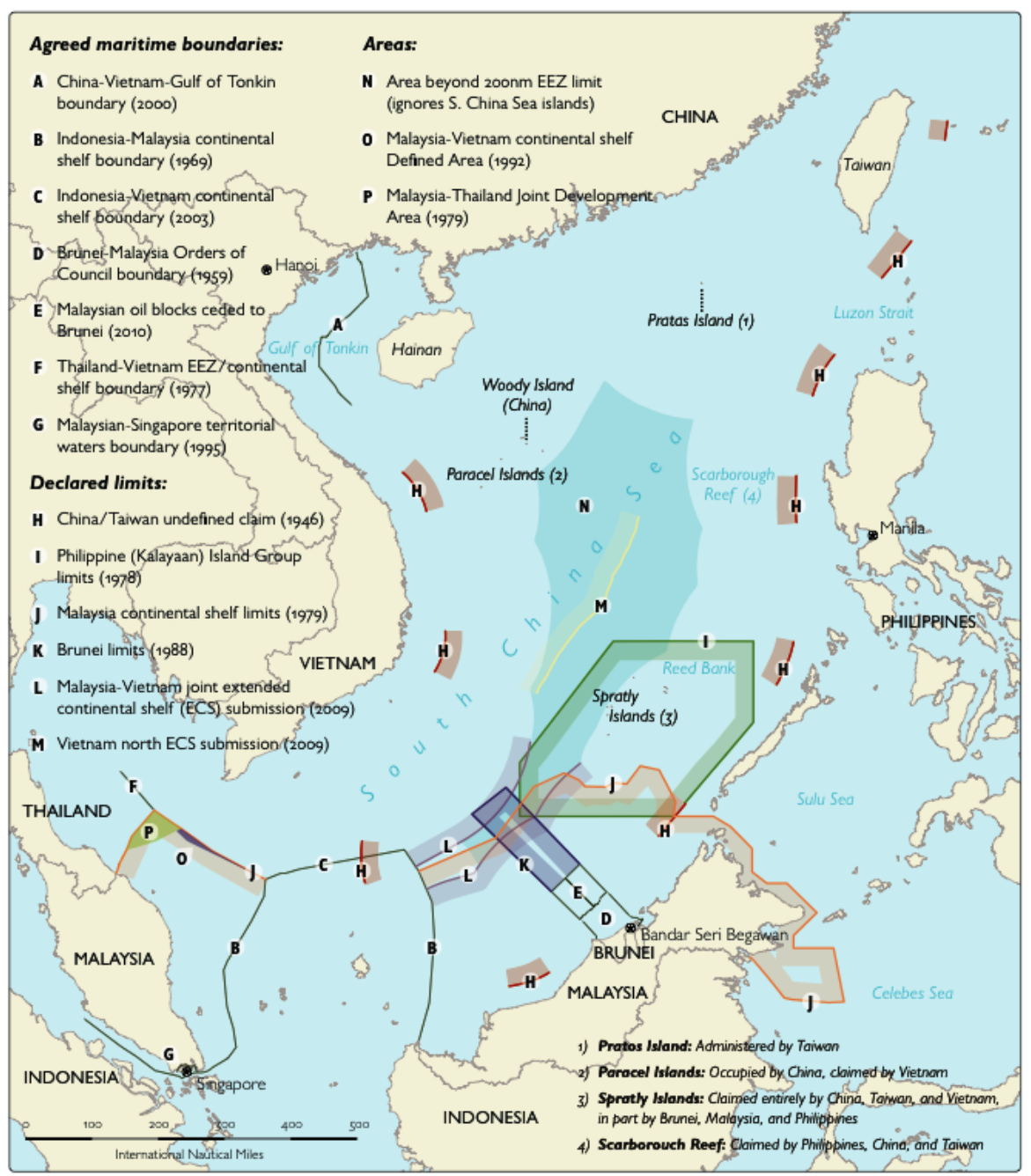

Source: U.S. Department of Defense's Annual Report on China to Congress (2012)

During 2011, there were, at least, three events which illustrate the growing use of China's hard power measures in the South China Sea conflicts. First, China often unilaterally patrol the South China Sea and expel other countries' traditional fishing boats. In fact, Chinese People Liberation Army-Navy is reported firing some warning shots at the Filipino trawler near the Jackson atoll on 25 February 2011 and Vietnamese fishing boats on 1 June 2011 (Jamandre, 2011). Second, China has deliberately used the vessel of the paramilitary maritime law enforcement agency, namely China Marine Surveillance (CMS), to actively block foreign vessels from conducting research and exploration in the disputed area regardless their Executive Economic Zone (EEZ) claim. Two CMS vessels dispelled Filipino-owned vessel MV Veritas Voyager near Reed Bank on 3 March 2011. On 26 May 26 2011, CMS vessels intentionally cut the seismic survey cables 
of Petro Vietnam vessel Binh Minh 02 within the area of Vietnam's EEZ (Storey, 2011b, pp. 2-3). Likewise, when Hanoi complained about China's actions in flaring tensions in Vietnamese waters, the Chinese response was an explicit warning for Vietnam to stop any activities 'where China has its claims' (Gomez, 2011). Third, despite the visit of Chinese Defense Minister, General Liang, to Manila and the joint agreement between China and The Philippines to refrain any unilateral action on 23 May 2011, Beijing allegedly kept installing markers at Reed Bank, Amy Douglas Reef, and Boxall Reef which are well within the Philippines' EEZ (Mogato, 2011; Pazzibugan, 2011).

Beijing's growing hard power measures also occurred in 2012. The Philippine navy sent its warship to the area of Scarborough Shoal, 220 kilometers west of Zambales and also within the Philippine's EEZ, after spotted eight Chinese fishing boats anchored inside the lagoon. Soon after that 'two Chinese surveillance ships arrived and taken up a position at the mouth of the lagoon', creating standoff and preventing the arrest of the Chinese fishermen' (CNN, 2012; Dupont \& Baker, 2014). Moreover, China also began enforcing the fishing band in larger area of South China Sea in May 2012, including the disputed Scarborough Shoal (The Jakarta Post, 2012). By July 2012, Beijing dispatched its fisheries law enforcement command on and erected a barrier to the entrance of the disputed shoal (Pazzibugan, 2011). The Chinese government even promulgated local law in December 2012 which authorized the law enforcer to board and seize control of foreign ships which enter the Chinese-claimed waters and order them to change course or stop sailing (Banchard \& Mogato, 2012).

The abovementioned Beijing's measures in the South China Sea have eventually triggered negative reprisals in the region, especially with how some Southeast Asian countries rapidly upgraded their naval capability. These actions are basically a harbinger of regional instability, and more importantly, to the degree of Southeast Asian confidence of China's menacing intention (Banlaoi, 2010). Likewise, Beijing's diplomacy in Southeast Asia has suffered a series of setbacks since 2009. While the issue of China's aggressiveness was hardly securitized in the previous forum of ASEAN dialogue, the ASEAN Regional Forum (ARF) in 2010 finally raised the issue in regional public debate. In fact, some Southeast Asian countries, especially Vietnam and the Philippines, pushed for the involvement of other great power, particularly the US, in the debate (ASEAN, 2010).

Indeed, although the growing Southeast Asian concern over China's hard power measures in the South China Sea is apparent, it does not mean that all countries in the region have the exact same degree of grievance. There are still diverse forms of reactions from Southeast Asian countries, especially with regards to each country's economic dependency and security concern towards China (Khong, 2004, pp. 192-197). While some Southeast 
Asian countries, such as Cambodia, Laos and Myanmar, generally have a closer relations and cooperation with China, other countries, such as Singapore, Malaysia, Thailand, and Indonesia, tend to show a more cautious and circumspect manner, largely due to the concern in maintaining regional stability. However, the Philippines and Vietnam have become more assertive in resisting China's domination in the region. As such, both countries have been supporting for the internationalization of South China Sea issues beyond China-ASEAN framework, including advocating for US's involvement as a counter balance measures (Chongkittavorn, 2011).

Nevertheless, one shall clearly see the emerge of a new distinct pattern in the Southeast Asian reactions towards China's growing hard power measures in the South China Sea conflicts. The disconnected message between Beijing's good image projection and its actual actions in the South China Sea conflicts inevitably generated grievances, induced counter-measures, and ultimately, exacerbated China's soft power. With the fact that the characteristics of suspicious and mistrust still prevail in the region, Southeast Asian countries have the opportunity to internalize the concern over Beijing's hard power measures in the South China Sea among its regional. As a result, there is now a growing trend in openly discussing the South China Sea issues in the ASEAN-related forums, such as the ARF's joint statement in 2010 and EAS's joint statement in 2011.

\section{Revisiting China's Soft Power}

The development of Beijing's hard power measures in the South China Sea has eventually incited the growing 'threat perceptions' in the region. But how it actually affects China's soft power? Acknowledging reputation can turn into an essential source for inducing other states to respect and follow a particular state's articulation, certain aspects that affects a particular country's reputation can also acts as an important reference for other states in acting and responding to its environment (Hall, 2010, pp. 207-211). In the case of China-Southeast Asia relations, the growing 'threat perceptions' that Southeast Asian countries have against China are deemed as the crucial element in eroding a state's reputation as the source of its soft power.

There are two sources for identifying the weakening of its soft power. Firstly, one can see the effects of China' measures in South China Sea on its soft power via investigating the Southeast Asian elites' perception. As Southeast Asian elites maintain a strong role in foreign policy's decision-making and policy implementation process (Tilman, 1984, pp. 2-3), their perspectives reflect the attitude toward other states and the efficacy of their respective soft power performance. Secondly, the identification of how China's soft power is affected by its growing assertive measures in the South China Sea can also be identified by the second source, namely the degree of favorability in public opinion. As the government is expected to respond to its 
people's aspirations, the public mood may act as an essential stimulant for the state' attitude and action towards other states; and in the same time, display the result of other states' soft power projection.

Indeed, it is difficult to claim that there is a coherent and persistent perception of China among Southeast Asian elites. However, political elites in both Vietnam and the Philippines started demonstrating a striking perception of China, especially in their public statements. In his response statement to the Beijing's action in the Binh Minh incident in May 2011, PM Nguyen publicly noted that 'we continue to affirm strongly and to manifest the strongest determination of all the [Vietnam's Communist] Party, of all the people and of all the army in protecting Vietnamese sovereignty in maritime zones and islands of the country', signaling a deep distrust of China (Agence France-Presse, 2012). Moreover, in the Shangri-La Dialogue Forum in 2011, Vietnamese General Phung Quang Thanh specifically cited that 'China has violated the DoC, raising concern in Vietnam and in the rest of the region' (IISS, 2011). Likewise, Filipino Secretary of Defense Voltaire Gazmin also expressed his concern about Beijing's growing threat in his reference to another incident in May 2011 involving China in the Filipino-claimed area. Gazmin specifically underlined the importance of the Philippines' 'robust alliance with the US' for tackling the growing China's threat in the South China Sea and ensuring the freedom of navigation in the region (IISS, 2011).
Moreover, Southeast Asian countries have also eventually signaled a reaction to Beijing's hard power measures in the South China Sea, indicating a growing shared perception of China in the region. While prior to 2010 ASEAN generally demonstrated its affinity to China, some Southeast Asian countries signaled a new political message within ASEAN-led regional mechanisms. All countries represented at the EAS in 2011, for instance, agreed to discuss the regional concern over the South China Sea conflicts and embrace the US as a new member of EAS. Given the symbolic gesture, namely the involvement of other great power outside China in the region and the suggestion that the current tension should be carefully managed on the basis of 'multilateral resolution of the conflicting territorial claims' (Calmes, 2011), the EAS statement signaled how most ASEAN countries accepted the growing Beijing's activities in the region as a real concern. Besides EAS, this particular concern was also affected ASEAN internal mechanisms. Despite not reaching a consensus, ASEAN Foreign Ministers' Meeting in 2012 discussed the Philippines and Vietnam's concern about how Beijing was imposing 'its claim over the entire South China Sea and raising the risk of a conflict' (Thul \& Grudgings, 2012). This meeting created a new precedent where 'ASEAN way of consensus failed' and some countries held a strong and extreme perception of China (Emmerson, 2012).

The above responses, indeed, signify the problem of Beijing's soft power projection. Denoting the Nye's primary 
definition of soft power as the ability of a state's allure in shaping the behavior of other countries, the shifting of ASEAN's perspective and attitude to the opposite of China's strategic interests, have shown a major change in the strength of Beijing's soft power in Southeast Asia. Some Southeast Asian countries' elite perceptions, especially from Vietnam and the Philippines, have indicated that Beijing's aggressive measures in the South China Sea were perceived as excessive or inappropriate actions. Aligning with $\mathrm{Li}$ (2009) argumentation, the inappropriate utilization of hard power, which is formed the 'threat perception', can result in the demise of its soft power. Instead of Beijing's good image and reputation projections that primarily affect Southeast Asian countries' policy, the other forms of action-i.e. its growing hard power measures in the South China Sea, - has increasingly led elites in other countries to doubt Beijing's reputation and act in contrary to the interests of China itself.

Beyond the Southeast Asian elites' statements, one can also indicate the weakening of Beijing's soft power through the declining popular favorability towards China, especially after the growing of its hard power measures in the South China Sea. This condition is reflected in the public opinion in showing how China is perceived. Pew Research Database (2017), for example, reveals a distinct trend of China's favorability. Although the research data base is limited to some countries in Southeast Asia, this data shows the dynamics of Southeast Asian response towards China. From Table 1, one can see that while showing a good respond to China in 2002, Vietnam and the Philippines signaled a dramatic change in the growing of unfavorable perception of China. Both countries showed a relative higher number of unfavorable views of China in 2014, especially with 78 percent of the surveyed people in the Philippines and 58 percent of the surveyed people in the Philippines regarding China negatively.

Table 1. Percentage of Southeast Asian countries' unfavorable responds to China

\begin{tabular}{|l|l|l|l|l|}
\hline Country & 2002 & 2013 & 2014 & 2015 \\
\hline Vietnam & 18 & - & 78 & 74 \\
\hline $\begin{array}{l}\text { The } \\
\text { Philippines }\end{array}$ & 30 & 48 & 58 & 43 \\
\hline
\end{tabular}

Source: adapted from Database Pew Global Attitudes Project - Pew Research Centre 2017

Likewise, the BBC World Service Poll (2011) provides a similar data on the rising doubt over China's amicable intention in the region. The BBC World Service Poll data reveals that some countries in Southeast Asia, especially the Philippines, have shown a gradual declining positive perception towards China. Whereas 54 percent of the surveyed people in the Philippines showing positive view in 2006, the favorability towards China dropped rapidly in 2009, resulting in only 39 percent of the surveyed people maintaining such positive view. This is certainly not a standalone phenomenon. Linking this trend with the record of how Beijing builds its soft power, we can see 
this trend as the weakening of China's capability in projecting benign image in Southeast Asia since its heyday in the first half of 2000s. Despite it had been actively wielding soft power projection as a 'peaceful' country since its official campaign in 2003, Beijing's foreign policy was not perceived as a genuine characterization of its 'peaceful' rise campaign. In Southeast Asia, this condition was well apparent with a growing external context outside Beijing's active in efforts building its soft power.

Table 2. Change in the views on China's influence in Southeast Asian countries

\begin{tabular}{|c|c|c|c|c|}
\hline & \multicolumn{2}{|c|}{2006} & \multicolumn{2}{c|}{2009} \\
\hline & $\begin{array}{c}\text { mainly } \\
\text { positive }\end{array}$ & $\begin{array}{c}\text { mainly } \\
\text { negative }\end{array}$ & $\begin{array}{c}\text { mainly } \\
\text { positive }\end{array}$ & $\begin{array}{c}\text { mainly } \\
\text { negative }\end{array}$ \\
\hline $\begin{array}{c}\text { The } \\
\text { Philippines }\end{array}$ & 54 & 30 & 39 & 52 \\
\hline
\end{tabular}

Source: adapted from BBC World Service Poll 2011

During the latter half of 2000s, there is a growing discrepancy between China's perceived intention and capability in terms of its economic and military, especially in the form of bigger anxiety over China's military threat compare to the confidence of China's economic collaboration tendency (BBC World Service Poll, 2011). Table 3, for instance, indicates the dissonance of Beijing's image in Southeast Asia and, therefore, the paradox of its soft power strategy in the region. While China's soft power projection was in line with the development of the positive belief on its economic rise, the increasing Beijing's assertive measures in the South China Sea also added to a growing perception that China is a threat to regional security. BBC World Service Poll (2011) even shows that there is a sharp contrast in the Philippine's public view on China's military capability. Whereas 46 percent of the surveyed people showing unfavorable view of
China's military capability in 2005, the number of negative perceptions rose rapidly to 63 percent of the surveyed people in the Philippines in 2011 (GlobeScan, 2011).

This dissonance between the perception on Beijing's economic and military rise eventually affected China's reputational power as the source of its soft power. With the growing discrepancy between its good reputation projection and actual action in the South China Sea, the ability of China's soft power in influencing other countries was weakened. Table 2 and Table 3 demonstrate the decline of China's positive image in the Philippines' public opinion and the link to Beijing's growing hard power measures in the region. This becomes even clearer if we link the decreasing public favorability of China and the increasingly tougher Southeast Asian elites' statements on Beijing's policy 
in the region. The existence of Beijing's hard power measures in the Table 3. The discrepancy in the opinion on China's economic and military concern in 2011

\begin{tabular}{|c|c|c|c|c|}
\hline & \multicolumn{2}{|c|}{$\begin{array}{c}\text { China Becoming More } \\
\text { Powerful Economically }\end{array}$} & \multicolumn{2}{c|}{$\begin{array}{c}\text { China Becoming More } \\
\text { Powerful Militarily }\end{array}$} \\
\hline & Positive & Negative & Positive & Negative \\
\hline $\begin{array}{c}\text { The } \\
\text { Philippines }\end{array}$ & 61 & 32 & 29 & 63 \\
\hline
\end{tabular}

Source: adapted from BBC World Service Poll 2011

South China Sea has influenced the narrative of China's reputation and its soft power in Southeast Asia. Indeed, the overall data presented cannot be deemed to rule out that there are diverse Southeast Asian countries' reactions and perceptions towards China (Goh, 2007, pp. 823-824). However, at the same time, one shall also note that the shifting of Southeast Asian elites and public opinions towards China reflects an essential and unprecedented gesture in the China-Southeast Asia relations.

Ultimately, the findings in this case vividly exemplify the importance of perception of China's behavior. As one of the most influential major countries in Asia, China still has real impediments in wining 'hearts and minds' of its neighboring region. Notwithstanding its complexity, this also underlines the importance of reconsidering the notion of 'soft power' and how it cannot be separated from other aspects in the international arena. Learning from the context of Southeast Asia, it is important for China to consider a nimbler approach in Southeast Asia, such as reconsider its hard power measures in the South China Sea and developing the use of military approach for the soft power purpose. Hence, with a better coordinated strategy, China can project a clear message in easing the threat perception in Southeast Asia and building a more coherent reputation as a benign country in the world.

\section{Conclusion}

Realizing the complex relationship between its image projection and actual actions in Southeast Asia, China's experience has marked an important illustration of the logic and nature of soft power. China has made a significant transformation to wield its soft power in an appealing way. More importantly, China has demonstrated its ability in reducing suspicion and building a benign 'responsible global stakeholder' image in the post-Cold War era. However, along with Beijing's increasingly active hard power measures in the South China Sea since 2009, there has been a growing concern over China's intention in the region. This uniquely added a new 
complexity in how Southeast Asian countries perceive and react to China.

The existence of many, albeit not all, Southeast Asian countries' actions against China, especially in ASEANrelated forums and its bilateral relations, have become a major turning point in China-Southeast Asia relations. At this juncture, one can see the growing threat perception from the increasingly Beijing's hard power measures in the South China Sea affect its soft power, particularly in the form of inciting 'threat perceptions' among Southeast Asian elites and public opinions. This, in turn, casted doubt on Beijing's virtue and real intention in the region, eroding China's 'reputational power' as the source of its soft power. The South China Sea conflicts, in fact, have vividly demonstrated the fragility of China's soft power in the region.

In summary, beyond the focus on the possibility for open conflict in the South China Sea, it is important to see other political implications in the region, especially on Beijing's soft power efforts in Southeast Asia. As China's soft power it is still muddling through the current problem of the South China Sea conflicts, the only certain thing is that the remaining threat perception from the repercussion of its hard power measures will affect further the source of its soft power. The prospect of China's soft power in Southeast Asia will rely on how Beijing can ponder the broader aspects of wielding its soft power effectively, such as the consideration of minimalizing the perceived-excessive measures in South
China Sea and the ability to project its reputational power through a better understanding of Southeast Asian regional contexts.

\section{About the Author}

The author is a lecturer at the Department of International Relations, Faculty of Social and Political Sciences, Universitas Gadjah Mada, Indonesia. His research interests span Chinese foreign policy, the politics of international regimes, and ASEAN studies. This article is adapted from the author's master dissertation at the S. Rajaratnam School of International Studies, Nanyang Technological University, Singapore. The author would like to express his gratitude to Ms. Ambar Widiastuti, Ms. Ezka Amalia, and Mr. Jonathan Rayon for their help during the research and the writing processes.

\section{References}

Acharya, A. (2003a). Seeking Security in the Dragon's Shadow: China and Southeast Asia in the Emerging Asian Order. Institute of Defence and Strategic Studies Singapore's Working Paper, 44, 1-27.

Acharya, A. (2003b). Will Asia's Past be Its Future? International Security, 28(3), 149-164.

Agence France-Presse. (2011, June 9). Vietnam PM says sea sovereignty 'incontestable'. Straits Times [online]. Retrieved January 19, 2012, from http://www.straitstimes.com/Break 
ingNews/SEAsia/Story/STIStory 6 77930.html

Archick, K., Grimmett, R. F., \& Kan, S. (2005). European Union's Arms Embargo on China: Implications and Options for U.S. Policy. CRS Report for Congress. Retrieved January 19, 2012, from http://www.fas.org/sgp/crs/row/RL 32870.pdf

ASEAN. (2010). 43rd AMM/PMC/17th ARF VIETNAM 2010 Chairman's Statement 17th ASEAN Regional Forum. ASEAN [online]. Retrieved January 9, 2019, from https://asean.org/?static post $=43 \mathrm{rd}$ -ammpmc17th-arf-vietnam-2010chairman-s-statement-17th-aseanregional-forum-ha-noi-23-july-2010

Baldwin, D. A. (1999). Force, Fungibility, and Influence. Security Studies, 8(4), 173-183.

Banchard, B., \& Mogato, M. (2012, November 29). Chinese Police Plan to Board Vessels in Disputed Seas. Reuters [online]. Retrieved January 9, 2019, from https://www.reuters.com/article/us -china-seas/chinese-police-plan-toboard-vessels-in-disputed-seasidUSBRE8AS05E20121129

Banlaoi, R. C. (2010). Renewed Tensions and Continuing Maritime Security Dilemma in the South China Sea. In T. Thuy (Ed.), The South China Sea: Cooperation for Regional Security and Development (pp. 143-159).
Hanoi: Diplomatic Academy of Vietnam.

BBC World Service Poll. (2011, March 27). Rising Concern about China's Increasing Power: Global Poll. BBC World Service [online]. Retrieved January 19, 2012, from http://www.worldpublicopinion.or g/pipa/pdf/mar11/BBCChina_Mar1 1 rpt.pdf

Brahm, L. (2001). China's Century: The Awakening of the Next Economic Powerhouse. Singapore: Wiley.

Carr, E. H. (1949). The twenty years' crisis, 1919-1939: an introduction to the study of international relations. London: Macmillan.

Calmes, J. (2011, November 19). Obama and Asian Leaders Confront China's Premier. The New York Times [online]. Retrieved January 19 , 2012, from http://www.nytimes.com/2011/11/2 0/world/asia/wen-jiabao-chineseleader-shows-flexibility-aftermeetingobama.html? r=1\&pagewanted=all

CNN. (2012, April 11). China, Philippines Locked in Naval Standoff. CNN [online], Retrieved January 9 2019, from

https://edition.cnn.com/2012/04/11/ world/asia/philippines-chinanavalstandoff/index.html

Cho, I. H., \& Park, S. H. (2013). The Rise of China and Varying Sentiments in Southeast Asia toward Great 
Powers. Strategic Studies Quarterly, 7(2), 69-92.

Chongkittavorn, K. (2011, June 7). Regional Neighbours See the Rise of China Differently. The Irrawaddy [online]. Retrieved January 19, 2012, from http://www.irrawaddy.org/article. php?art id=21442\&page $=2$

Deng, Y. (2006). Reputation and the Security Dilemma: China Reacts to the China Threat Theory. In A. Johnston., \& R. Ross (Eds.), The New Directions in the Study of China's Foreign Policy (pp. 186-214). Stanford: Stanford University Press.

Dupont, A., \& Baker, C. (2014). East Asia's Maritime Disputes: Fishing in Troubled Waters. The Washington Quarterly, 37(1), 79-98.

Emmers, R. (2010). Geopolitics and Maritime Territorial Disputes in East Asia. New York: Routledge.

Emmerson, D. (2012, July 23). ASEAN Stumbles in Phnom Penh. East Asia Forum [online]. Retrieved January 6, 2019, from https:// www.eastasiaforum.org/2012/07/23 Lasean-stumbles-in-phnom-penh-2/

Er, L.P., Narayanan, G., \& Colin, D. (Eds). (2010). East Asia's Relations with a Rising China. Seoul: Konrad Adenauer Stiftung.

Globescan. (2011, March 27). Rising Concern about China's Increasing
Power: Global Poll. Globescan [online]. Retrieved January 9, 2019, from https://globescan.com/risingconcern-about-chinas-increasingpower-global-poll/

Goh, E. (2007). Southeast Asian Perspectives on the China Challenge. The Journal of Strategic Studies, 30, 809-832.

Gomez, J. (2011, June 9) 'China warns neighbours: Stop oil search in Spratlys'. Associated Press [online]. Retrieved January 19, 2012, from http://www.guardian.co.uk/world/ feedarticle/9687830

Green, M., \& Daniel, K. (2011). China's Hard Power and the Potential for Conflict in Asia. SERI Quarterly, $4(2), 32-41$.

Guo, S., \& Jean-Marc F. (Eds.). (2008). 'Harmonious World' and China's New Foreign Policy. Lanham: Lexington Books.

Hall, T. (2010). An Unclear Attraction: A Critical Examination of Soft Power as an Analytical Category. The Chinese Journal of International Politics, 3(2), 189-211.

Huang, Y., \& Sheng D. (2006). Dragon's Underbelly: An Analysis of China's Soft Power. East Asia, 23(4), 22-44.

Jamandre, T. (2011, June 3). China fired at Filipino fishermen in Jackson atoll, $A B S-C B N$ Interactive [online]. Retrieved January 19, 2012, from 
http://ph.news.yahoo.com/chinafired-filipino-fishermen-jacksonatoll-184604882.html

Jayakumar, S. (2011). Key note address at the Conference on Joint Development and the South China Sea, Thursday, 16 June 2011, in Singapore. Singaporean MFA [online]. Retrieved 19 January 2012, from http://app.mfa.gov.sg/pr/read cont ent.asp?View,15634

Jintao, H. (2007, October 15). Retrieved from BeijingReview.com.cn: http://www.bjreview.com.cn/17thC PC/txt/2007-

\section{0/15/content 80539.htm}

Jones, D. M., \& Smith, M. (2007). Constructing Communities: The Curious Case of East Asian regionalism. Review of International Studies, 33(1), 165-186.

Kang, D. (2003). Getting Asia Wrong: The Need for New Analytical Frameworks. International Security, 27(4), 57-85.

Karim, M., \& Tangguh, C. (2016). Waiting for Hard Balancing? Explaining Southeast Asia's Balancing Behaviour towards China. European Journal of East Asian Studies, 15(1), 34-61.

Katzenstein, P. J., \& Rudra, S. (2004). Rethinking Asian Security: A Case for Analytical Eclecticism. In J. J. Suh, Peter J. Katzenstein, A. Carlson (Eds.), Rethinking Security in East Asia (1-33). Stanford: Stanford University Press.

Khong, Y. F. (2004). Coping with Strategic Uncertainty: The Role of Institutions and Soft Balancing in Southeast Asia's Post-Cold War Strategy. In J.J. Suh, Peter J. Katzenstein, A. Carlson (Eds.), Rethinking Security in East Asia: Identity, Power, and Efficiency (pp. 172-208). Stanford: Stanford University Press.

Krauthammer, C. (1995, July 31). Why We Must Contain China. Time [online]. Retrieved January 20, 2019, from http://content.time.com/time/maga zine/article/0,9171,983245,00.html

Kristof, N. D. (1998, November). The Problem with Memory. Foreign Affairs [online]. Retrieved January 19, 2012, from https://www.foreignaffairs.com/art icles/asia/1998-11-01/problemmemory

Kurlantzick, J. (2007). Charm Offensive: How China's Soft Power is Transforming the World. New Haven: Yale University Press.

Lampton, D. M. (2008). The Three Faces of Chinese Power: Might, Money and Minds. Berkeley: University of California Press.

Li, M. (2008). Security in the South China Sea: China's Balancing Act and New Regional Dynamics. RSIS Working Paper, (149), 1-22. 
Li, M. (2009). Soft Power: China's Emerging Strategy in International Politics. Lanham: Lexington Books.

Lukes, S. (2005). Power: A Radical View (2 ${ }^{\text {nd }}$ ed.). New York: Palgrave Macmillan.

Macikenaite, V. (2014). The Implications of China's Fisheries Industry Regulation and Development for the South China Sea Dispute. In D. Mierzejewski (Ed.), The Quandaries and Foreign Development (pp. 216236). Poland: Wydawnictwo Uniwersy tetu Łódzkiego.

Mearsheimer, J. (2001). The Tragedy of Great Power Politics. New York: W.W. Norton \& Company.

Mogato, M. (2011, May 23). Philippines, China seek restraint in the South China Sea. Reuters [online]. Retrieved January 19, 2012, from http://in.reuters.com/article/2011/0 5/23/idINIndia-5720492011052 3

Nanto, D. K. (2008). East Asian Regional Architecture: New Economic and Security Arrangements and U.S. Policy. CRS Report for Congress [online]. Retrieved January 19, 2012,

from http://www.fas.org/sgp/crs/row/RL 33653.pdf

Novotny, D. (2010). Torn between America and China: Elite perceptions and Indonesian Foreign Policy. Singapore: ISEAS.
Nye, J. S. Jr. (2002). The Paradox of American Power. New York: Oxford University Press.

Nye, J. S. Jr. (2004). Soft Power: The Means to Success in World Politics. New York: Public Affairs.

Nye, J. S. (2005). Soft Power The Means To Success In World Politics. New York: PublicAffairs.

Ott, M. (2011). ASEAN and the South China Sea: A Security Framework under Siege. CSIS - the South China Sea Papers [online]. Retrieved January 19, 2012, from https://www.csis.org/analysis/asea n-and-south-china-sea-securityframework-under-siege

Pan, Z. (2008). China's Changing Image of and Engagement in World Order. In S. Guo and Jean-Marc. F. Blanchard, 'Harmonious World' and China's New Foreign Policy (pp. 3963). Lanham: Lexington Books.

Pazzibugan, D. Z. (2011, June 16). 'Philippines pulls Spratlys 'foreign' posts'. Philippine Daily Inquirer [online]. Retrieved January 19, 2012, from http://newsinfo.inquirer.net/15230/ philippines-pulls-spratlys-foreignposts

Percival, B. (2007). The Dragon Looks South: China and Southeast Asia in the New Century. Westport, Connecticut: Praeger Security International. 
Pew Research Database. (2017). 'China', [Online]. Retrieved December 19, 2017, from https://www.pewglobal.org/topics/ china/

Rajagobal, N. (2016, July 12). The 2009 Claims that Changed the Dynamics in the South China Sea. The Strait Times [online]. Retrieved January 9, 2019, from https://www.straitstimes.com/opin ion/the-2009-claims-that-changeddynamics-in-the-s-china-sea

Roy, D. (1996). The China Threat Issue: Major Arguments. Asian Survey, 38(8), 758-771.

Rozman, G. (2010). Chinese Strategic Thought toward Asia. New York: Palgrave Macmillan.

Senkar, O. (2004). The Chinese Century: The Rising Chinese Economy and Its Impact on the Global Economy, the Balance of Power, and Your Job. New Jersey: Prentice Hall.

Shirk, S. L. (2007). China: Fragile Superpower: How China's Internal Politics Could Derail Its Peaceful Rise. New York: Oxford University Press.

Storey, I. (2011a). Southeast Asia and the Rise of China: The Search for Security. New York: Routledge.

Storey, I. (2011b). Hardening Positions over Dangerous Grounds: Recent Developments in the South China Sea Dispute. CSIS [online].
Retrieved January 19, 2012, from https://www.csis.org/analysis/hard ening-positions-over-dangerousgrounds-recent-developmentssouth-china-sea-dispute

Storey, I. (2013). Southeast Asia and the Rise of China: The Search for Security. London: Routledge.

Sutter, R. (2008). Chinese Foreign Relations: Power and Policy since the-Cold War. Lanham: Rowman and Littlefield Publisher.

Tang, S., Mingjiang, L., \& Acharya, A. (Eds.). (2009). Living with China: Regional States and China through Crises and Turning Points. New York: Palgrave Macmillan.

Thayer, C. A. (2010). Recent Development in the South China Sea: Grounds for Cautious Optimism? RSIS Working Paper, (220).

The International Institute for Strategic Studies [IISS]. (2011). Report of 10th IISS Asia Security Summit [online]. Retrieved January 19, 2012, from http://www.iiss.org/publications/c onference-proceed ings/shangri-ladialogue-report-2011/

The Jakarta Post. (2012, May 14). China to Enforce Fishing Ban in Disputed Waters. The Jakarta Post [online]. Retrieved January 9, 2019, from https://web.archive.org/web/20120 517014221/http://www.thejakartap ost.com/news/2012/05/14/chinaenforce-fishing-ban-disputedwaters.html 
The State Council Information Office. (2006). 'White Paper on China's Peaceful Development Road'. China Report, 42(215). Retrieved January 19, 2012, from http://chr.sagepub.com/cgi/reprint/ $\underline{42 / 2 / 21}$

Thul, P. C., \& Grudgings, S. (2012, July 13). SE Asia Meeting in Disarray over Sea Dispute with China. Reuters [online]. Retrieved January 9, 2019, from

https://www.reuters.com/article/us -asean -summit/se-asia-meeting-indisarray-over-sea-dispute-withchina-idUSBRE86C0BD20120713

Thuy, T. T. (2011, July 15). Recent Development in the South China Sea: From Declaration to Code of Conduct. East Sea Studies [online]. Retrieved January 9, 2019, from http://nghiencuubiendong.vn/en/c onferences-and-seminars-/secondinternational-workshop/586recent-development-in-the-southchina-sea-from-declaration-tocode-of-conduct-by-tran-truongthuy

Tilman, R. O. (1984). The Enemy Beyond: External Threat Perceptions in the ASEAN Region. Singapore: ISEAS.

Wang, H. (2011). China's Image Projection and Its Impact. In Wang Jian (Ed.), Soft Power in China: Public Diplomacy through Communication (pp. 37-56). New York: Palgrave Macmillan.
Wong, E. (2010, April 23). Chinese Military Seeks to Extend Its Naval Power. The New York Times [online]. Retrieved September 7, 2011, from http://www.nytimes.com/2010/04/2 4/world/asia/24navy.html?pagewa $\underline{\text { nted }=\text { all }}$

Yan, X. (2006). The Rise of China and Its Power Status. The Chinese Journal of International Politics, 1(1), 5-33.

Zheng, B. (2005). China's Peaceful Rise: Speech of Zheng Bijian 1997-2005. Washington DC: Brookings Institution Press. 